Отримано: 15.10 .2020 р.

Прорецензовано: 20.11.2020 p.

Прийнято до друку: 02.12.2020 p.

e-mail: nataliaivanivnaboiko@gmail.com

DOI: $10.25264 / 2409-6806-2020-31-41-49$
Бойко Н. Міграційна політика Сполученого Королівства та міграція 3 України (1990-2020 рр.). Наукові записки Наџіонального університету «Острозька академія». Серія «Історичні науки». Острог, 2020. Вип. 31. C. $41-49$.

\title{
Наталія Бойко
}

\section{МІГРАЦІЙНА ПОЛТТИКА СПОЛУЧЕНОГО КОРОЛІВСТВА ТА МІГРАЦІЯ 3 УКРАЇНИ (1990-2020 РР.)}

Стаття присвячена міграчійній політиці британських урядів на сучасному етапі. Проаналізовано діючі міграційні закони, прийняті британськими урядами з 1990 р., з метою стримування $і$ контролювання потоків іммігрантів, їх наслідки для емігрантів з України зокрема. Особливу увагу зосереджено на міграційній складовій діяльності лейбористського уряду Тоні Блера і консервативного уряду Терези Мей, як найбільш лояльного та найбільш ворожсого в питаннях імміграції. Підкреслено значення ЗМІ та інформачійної пропаганди у відображенні імміграиії, як тренду британської внутрішньої політики та ключової причини Брексіту.

Ключові слова: імміграція, Великобританія, Брексіт, українські мігранти, нелегальні мігранти, міграчійна політика.

\section{Nataliia Boiko}

\section{UNITED KINGDOM MIGRATION POLICY AND MIGRATION FROM UKRAINE (1990-2020)}

The article is devoted to the formation and evolution of migration policy of British governments at the present stage. It is noted that migration processes are one of the main features of globalization. It is also claimed that the UK has always attracted migrants from different parts of the world, especially from the post-colonial countries and Eastern Europe. As a migration project, it has always been characterized by a high standard of living and a high level of wages in the European Union. However, as a member of the European Community until 2019, Britain has always differed from its European partners in its autonomy and separateness, particularly in the field of immigration policy.

The author analyzes the current migration laws passed by the British governments from 1990 to 2020. The active development of migration legislation began during the premiership of the conservative John Major (1990-1997). Therefore, the Conservative government has taken steps only in the direction of quota migration flows. It was determined that the basic purpose of the migration legislation of the United Kingdom was the governments' ability to comprehensively address the migration problem as a threat to national security. It was officially recognized during the reign of Gordon Brown (2007-2010). It has been proven that the priorities in the UK's migration policy have been the issues of restraining and controlling the flow of immigrants, in particular their consequences for immigrants from Ukraine. Special attention is paid to the migration component of the Labor government of Tony Blair (1997-2007) and the Conservative government of Theresa May (2016-2019) as the most loyal and hostile cabinet ministers on immigration. The competition between the party principles of controlled (Labor) and rigid (Conservative) migration under their rule has led to the adoption of new laws. In essence and content, they were designed to cope with the growing migration crisis in the country. The importance of the media and information propaganda in the reflection of immigration as a trend of British domestic policy and a key cause of Brexit (2016-2019) is emphasized.

Key words: immigration, Great Britain, Brexit, Ukrainian migrants, illegal migrants, migration policy.

Міграційні процеси є однією з головних особливостей глобалізації. 3 огляду на світову економічну та демографічну структуру ресурсів, саме вони спричиняють відтік і притік населення. Україна, як елемент світової глобалізації не $є$ винятком: із розпадом Радянського Союзу велика кількість українських громадян змушені були виїхати закордон у пошуках праці та засобів до існування. Останніми роками спостерігається нова міграційна хвиля, характерною рисою якої є вагоме збіль- 
шення кількості громадян з країн Близького Сходу, Північної Африки та частково Східної Свропи.

Однією з країн, яка завжди приваблювала українських мігрантів, була Великобританія. Вона як міграційний проєкт завжди вирізнялася високим рівнем життя i, чи не одним із найвищих, рівнем оплати праці в Європейському Союзі. Проте, будучи членом СС до 2019 р., Британія завжди відрізнялася від європейських партнерів своєю автономністю та окремішністю, зокрема в сфері імміграційної політики. Починаючи з 1960-х рр., коли поступово розпадалась Британська колоніальна імперія, уряд Великобританії зрозумів, необхідність регулювання напливу бажаючих відвідати країну і оселитися тут. Внаслідок цього, Великобританія стала чи не однією з перших європейських держав, що почали вводити обмеження на приїзд нових громадян, як із країн Співдружності чи Європи, так і з решти світу. Рестрикційна політика Великобританії справила неабиякий вплив на мігрантів з усього світу, в тому числі і українських.

Джерельну базу проблеми становлять закони про імміграцію та притулок, які були прийняті британськими урядами протягом 1990-2020 pр. Проблема впливу британського законодавства на українську міграцію до Великобританії не досліджена в українській історіографії. В основному українські науковці досліджують міграційну політику Великобританії в контексті спільної політики з СС. Серед них Л. Міхавчук [4; 5], а також російська дослідниця Т. Андрєєва [1]. Проблема системи надання притулку в Британії висвітлена в статтях українських науковців М. Воєводи та В. Колодяжної [2], зокрема діяльність уряду Джона Мейджора розглядає англійський історик К. Гарві [13] та білоруський - А. Зубарєв [3]. Вони сходяться в твердженнях про неготовність уряду Джона Мейджора до прийняття такої кількості шукачів притулку на початку 1990-х рр., а його діяльність в сфері міграції була реакцією на напливи великих потоків біженців у Великобританію. Питання нелегальної міграції з України розкрито в статті оксфордського науковця Ф. Дювеля, який стверджує, що Україна є постачальником нелегальних мігрантів на європейські ринки праці [9]. Варто згадати статтю О. Малиновської в співавторстві з британським істориком Б. Волмером, які характеризують українську еміграцію до Великобританії починаючи з часів «перебудови» [24]. Велику цінність становить звіт науковців Оксфордського університету [16], в якому міститься статистична інформація про українську еміграцію до Великобританії саме з 1990-х рр., адже на цей момент існує багато даних про мігрантів другої половини XX ст., проте британська статистика не називає кількість українців в Англії на сучасному етапі.

Основною метою цієї статті є аналіз імміграційної політики британських урядів протягом 19902020 pp. та iї наслідків; вплив на зміну загальної кількості іммігрантів та еволюції української еміграції до Великобританії.

Сучасна британська міграційна політика бере свої корені з часів розпаду Британської колоніальної системи. 3 1960-х рр. основою британської міграційної політики була стратегія подвійного інтервенціонізму. Саме тоді було прийнято ряд законів, які стосувалися, в основному, громадян Співдружності, і мали на меті обмеження їх прав на вільний в'їзд.

Переломним моментом в імміграційній політиці Британії стало прийняття закону «Про імміграцію» 1971 р. У ньому вперше було запроваджено категорії громадян «patrials», до яких відносили громадян Великобританії і всіх, хто народився в країнах Співдружності, а також ті, хто мали родинні зв'язки з ними, i «non-patrials» - особи, які не мали британського коріння, і які підпадали під імміграційний контроль. Після прийняття цього закону до тих, хто не мав права перебувати в країні, вперше почали застосовуватися депортації або ж 3 місяці ув'язнення [4, с. 129].

Вже в 1980-х рр. ситуація з міграцією сильно змінилася, що було пов'язано з кризою у балканських країнах, а також розпадом СРСР. На зламі 1980-1990-х рр. внаслідок розпаду СРСР і ряду політичних трансформацій в країнах Європи збільшилася кількість біженців та людей, які шукали притулку. Внаслідок цього подальші політичні реформи у Великобританії були спрямовані на обмеження кількості потенційних мігрантів тими чи іншими способами [5, с. 39]. В 1987 р. консервативний уряд М. Тетчер (1979-1990рр.) ввів Закон про імміграцію (так званий Закон про особисту відповідальність перевізників), згідно з яким, перевізники, які перевозили людей без необхідної документації, без візи або ж за фальшивими документами, несли особисту відповідальність у вигляді штрафу 1 тис. фунтів за особу або могли бути ув'язнені.

У свою чергу українцям, які хотіли виїхати з СРСР були введені суворі обмеження на виїзд, які були скасовані українським урядом лише в січні 1993 р. [22, с. 26]. Це ж стосувалося і всіх країн Центрально-Східної Європи. Така лібералізація переміщення сприяла притоку мігрантів до Сполу- 
ченого Королівства. На початку 1990-х рр. консервативна партія Великобританії почала поступово обмежувати право на отримання притулку, оскільки британська імміграційна система була не готова до такого напливу людей. Зрештою, про це свідчить той факт, що до 1990-х рр. імміграційні правила розроблялися і контролювалися саме Міністерством внутрішніх справ, а не парламентом, оскільки питання міграції не було настільки важливим для британського уряду [3, с. 64].

Кількість східноєвропейців, прийнятих на поселення у Великобританії, була незначна (у 1990 р. 640 осіб; у 1992 р. - 1180 осіб) [16, с. 8]. Крім того, складно виділити конкретну кількість українців, внаслідок узагальненого характеру даних, адже їх відносили до східноєвропейців, аж до 1998 р.

У 1993 р. був прийнятий закон «Про притулок та імміграційні апеляції». Закон звільнив уряд від обов'язку забезпечувати біженців житлом, а також дозволив затримувати осіб, яким було відмовлено у наданні притулку, до подальшої їх депортації. В аплікантів було всього 48 год., щоб подати апеляцію в разі відмови, крім того в них бралися відбитки пальців, для уникнення повторних запитів. Результатом стало збільшення відмов у наданні притулку з 14\% до 76\% у 1994 р [3, с. 66].

Проте вже з 1995 р. кількість біженців почала зростати: з 44 тис. в 1994 р. до 55 тис. в 1995 р., переважну більшість яких становили вихідці з африканських країн. Тому у 1996 р. було прийнято жорсткіший закон «Про імміграцію та надання притулку», який дозволив повертати шукачів притулку на їх батьківщину, якщо вона вважалася безпечною (відповідно формувався «білий список» безпечних країн). Тим, хто приїздили у Великобританію із цього списку автоматично відмовляли. Також, закон прискорив процедури подання апеляцій, обмежив соціально-економічні права шукачів притулку. Роботодавці, які приймали нелегалів, сплачували штраф 5 тис. фунтів. 3 червня 1994 - по червень 1996 рр. було виявлено 19,5 тис. нелегалів, з яких 6,3 тис. були депортовані [7, с. 33].

Внаслідок цього імміграція українців до Великобританії набула іншої форми, легальні трудові мігранти перестали бути переважаючою категорією, внаслідок обмежень британського уряду щодо низькокваліфікованих працівників. Це призвело до збільшення нелегальної міграції і з України [9, c. 3]. Проте, в 1990-х рр. серед українців, які прибули до Великобританії, були туристи, студенти та спеціалісти. Багато з них класифікувалися як висококваліфіковані мігранти та ділові люди. Упродовж 1991-2001 рр. кількість українців, які народилися в СРСР і проживали у Великобританії, збільшилась на 16 тис. [16, с. 8].

Ще за прем’єрства Дж. Мейджора (1990-1997 pp.) було підготовано проєкт, а в липні 1998 р. опубліковано «Білу книгу» «Справедливіше, швидше та жорсткіше - сучасний підхід до імміграції та притулку», в якій ішлося про необхідність вдосконалення системи надання притулку [24, с. 26].

Лейбористський уряд Т. Блера (1997-2007рр.) виявився найбільш продуктивним в плані законодавства: за 10 років було видано 7 законів, 2 білі книги і 5 стратегій розвитку держави в плані міграції. Проте, лейбористи не мали конкретно сформованої цілі щодо міграційної політики, хоча підтримували ідею збереження нульової міграції. Як стверджує дослідниця Вашингтонського університету Дж. Вагнер, Т. Блеру дісталася неефективна і провальна система надання притулку, внаслідок чого Британія стикнулася з великою кількістю біженців [24, с. 25]. Серйозним пом'якшенням імміграційного порядку було скасування правила «основної мети».

Неефективність системи надання притулку, зловживання з боку аплікантів і їх нелегальне проживання у країні після отриманні відмови стали основою закону 1999 р. «Про імміграцію та надання притулку», головною метою якого було змінення умов прийому іммігрантів [15]. Розгляд заяв біженців тепер тривав до двох місяців, тим кому відмовили дозволялася лише одна апеляція. Була створена Національна служба шукачів притулку. Нова система розширила ареал проживання біженців, що призвело до зростання невдоволення місцевого населення та поширенню насильства $\mathrm{i}$ ксенофобії, особливо до кольорових людей [12, с. 22]. Збільшувалися штрафи за ввезення нелегалів, а їх самих затримували.

Вже у 2001 р., коли Т. Блер вдруге став прем’єром, питання міграції стало одним із головних в його політичній програмі, оскільки кількість біженців швидко зростала: до 2002 р. вона становила щорічно 90 тис. осіб. Левова часка в підігріванні інтересу і ненависті до шукачів притулку належала ЗМI. Як зазначають дослідження центру Іпсос MOPI, з 2000-х рр. проблема міграції займала перші місця в опитуваннях громадян [8, с. 17].

За переписом 2001 р. в Британії проживало біля 12 тис. українців. Більшості з них (6537) було шістдесят і сімдесят років, більшість із них прибули до Великобританії після Другої світової війни 3 таборів для переміщених осіб у Німеччині, Австрії та Італії. Іншу значну групу склали українці 
віком від 15 до 44 років (4158), що, ймовірно, представляли імміграцію після 1991 р. Дані перепису 2001 р. також показують, що більшість українських іммігрантів були чоловіками; співвідношення чоловіків до жінок становили 58\% до $42 \%$ [16, с. 10].

Збільшення кількості мігрантів спричинило до появи нової Білої книги, в якій ішлося про те, що Великобританія не була місцем для шукачів притулку, натомість широко висвітлювались переваги трудової міграції, якої економіка Британії потребувала. Варто зазначити, що в цьому документі вперше йшлося про умову інтеграції іммігранта в британське суспільство, зокрема задля отримання громадянства.

У 2002 р. був прийнятий Закон «Про імміграцію, громадянство та притулок» мав на меті створення спеціальних центрів, де жили б шукачі притулку, в яких би проводилися програми щодо їх інтеграції в британське суспільство [17]. Нові потенційні іммігранти повинні були здавати тест на володіння англійською, а також знати особливості життя у Британії. В сфері нелегальної міграції, уряд надавав повноваження поліції проводити обшуки будинків, також збільшувалися штрафи.

Зовсім іншим було ставлення до трудових мігрантів, нестача яких, як вважалося, обмежувала країну в наданні послуг громадянам, зокрема в галузі медицини і освіти. Тому цим представникам було збільшено кількість дозволів на роботу: в 1995 р. - 1,6 тис., 1999 р. - 10,4 тис., 2003 р. - 44,4 тис. $[12$, c. 17$]$.

Головним документом, що стосувався даного періоду була Біла книга «Захищені кордони, тиха гавань: різноманіття форм інтеграції в сучасній Британії» 2002 р., в якій вперше оприлюднено стратегію «керованої міграції». Людей, талантів і вмінь яких потребувала британська економіка, запрошували легально працевлаштуватися: вже в 2000 р. кількість дозволів, виданих на роботу мігрантам сягала 85,6 тис., на відміну від 1995 р. - 24 тис. [26, с. 29]. Візові випробування були полегшені.

У січні 2002 р. уряд почав програму набору робітників поза межами Європейської економічної зони на основі бальної системи. Критерієм були 75 балів, які дозволяли привезти членів сім'ї з собою. Відповідно за цією програмою в 2002 р. було видано 1197 дозвіл на працю, а в 2008 - 17760 [26, с. 38]. Некваліфіковані мігранти були залучені до сфери сільського господарства, готельного бізнесу або харчової промисловості. Проте, їм не було дозволено привозити сім'ю і перебували вони тимчасово, відповідно до короткострокового контракту. Були полегшені умови в’їзду і для іноземних студентів.

Згідно Закону 2004 р. «Про надання притулку та імміграцію» [6] передбачалося створення електронного моніторингу осіб, що шукають притулок. Також звужувалися можливості апеляції для тих, кому було відмовлено. Закон вперше офіційно закріпив статус шукача притулку тимчасовим, а не постійним; позбавляли права притулку біженця, який був пов'язаний із терористичною діяльністю. Було створено систему електронного моніторингу біженців, їх голосів та відбитків пальців. За найм нелегалів на роботу могли посадити на два роки. Це позначилося на українських мігрантах, якщо в 2003 р. шукачів притулку було 300 осіб, то в 2004 - 55 [24, с. 9].

Розширення $С$ п призвело до значного збільшення емігрантів з Східної Європи: з травня 2004 - по вересень 2005 рр. на британському ринку праці зареєструвалися близько 30 тис. східноєвропейських громадян. Т. Блер вважав, що саме східноєвропейські мігранти зможуть заповнити потребу Британії в низькокваліфікованих працівниках.

Міжнародна організація з міграції (МОМ) підрахувала, що наприкінці 2005 р. у Великобританії проживало 100 тис. українців; до грудня 2006 р. - близько 120 тис., які вважали себе українцями та називали Британію домом [16, с. 17].

У 2006 р. був прийнятий закон «Про імміграцію, притулок та національність», який висвітлював 5-річну стратегію для Британії в плані притулку та імміграції [10, с. 43]. Він дозволив біженцям сповна користуватися правом апеляції, якщо вони не були пов'язані з тероризмом. Імміграційним офіцерам дозволялося конфісковувати документи мігрантів, включно з відбитками пальців, запроваджувалися біометричні тести. Людей із подвійним громадянством могли позбавити британського, якщо вони являли загрозу британському суспільному благу.

Переломний момент в системі щодо трудових мігрантів наступив у 2006 р., коли Міністерство внутрішніх справ оприлюднило звіт щодо введення нової балової візової системи [4, с. 132]. Вона остаточно поділила мігрантів на висококваліфікованих, яких суспільство потребує, і низькокваліфікованих, які не становили особливої цінності. Вона підпорядковувала наплив іммігрантів національним інтересам: Британія буде приймати лише тих мігрантів, які приносять користь країні. Було 
виділено 5 рівнів віз для бажаючих працювати в країні: висококваліфіковані працівники, середньокваліфіковані із запрошенням на роботу, низькокваліфіковані, студенти, різні тимчасові робітники.

За прем’ерства Г. Брауна (2007-2010рр.) був прийнятий закон «Про кордони Сполученого королівства» (2007) [23]. У ньому вперше було прив'язано питання імміграції до національної безпеки. Всі іммігранти зобов'язувалися оформити біометричний документ. За певний список проступків їх затримували на 12 місяців із подальшою депортацією без права на апеляцію. Він ознаменував прогрес у галузі ідентифікаційних технологій, запровадивши біометричну реєстрацію як необхідну вимогу для тих, хто в'їжджав до Великобританії.

У 2007 р. Міністерство внутрішніх справ Великобританії підрахувало, що більшість українських мігрантів $є$ членами возз'єднаних сімей або проживають нелегально. Дослідник Оксфордського університету Ф. Дювель стверджує, що Україна є постачальником не лише низькокваліфікованих працівників, а й нелегальних мігрантів [9, с. 5]. Відповідно щорічного опитування населення, кількість українців Великобританії протягом 2004-2008 рр. становила від 14 до17 тис. [16, с. 19].

Зауважимо, що Г. Браун не мав визначеної позиції у питаннях міграції. Спочатку він відмовився обмежувати кількість мігрантів, але вже в 2009 р. виступив за жорсткіші правила для імміграції. У Законі «Про імміграцію, злочин і правосуддя» було визначено іноземного злочинця (мігранта), як особу, яка не має права жити у Великобританії.

У 2009 р. був прийнятий Закон про імміграцію, громадянство та кордони. Він вперше дозволив офіцерам вирішувати питання пов'язані з митницею та доходами, зокрема мали доступ до інформації, що стосувалася іммігрантів. Звідси почалися перевірки доходів туристів, як потенційних іммігрантів, на рахунок того чи зможуть вони себе забезпечити перебуваючи в Британії. Також, закон дозволив брати відбитки пальців міжнародних злочинців [26, с. 37].

Таким чином, лейбористські уряди у своій діяльності намагалися дотримуватися принципів керованої міграції. Проте він зазнав краху, оскільки кількість мігрантів в країні постійно збільшувалася.

Міграційну політику лейбористів мали на меті реновувати консерватори. Під час виборчої кампанії 2010 р. вони обіцяли до 2015 р. зменшити «чисту міграцію» до «десятків тисяч» [21, с. 73]. У квітні 2011 р. Д. Кемерон визначив мігрантів з Африки і Південної Азії головними, що підпадають під скорочення. Політологи університету Сассекса і університету Королеви Марії в Лондоні Т. Бейл та Р. Партос вважають, що консервативна партія не повинна була довіряти посаду прем’єра людині 3 такими ліберальними поглядати на імміграцію [20, с. 170]. На думку авторів, політика консерваторів була відмінною від заявленої; вона була більш рестрикційною, жорсткішою та гіперактивною.

3 призначенням Т. Мей міністром внутрішніх справ (до обов'язків якого входять питання імміграції) почалася «тиха революція» в імміграційній політиці, зумовлена системою міграційних перевірок громадян і названа нею ж як «вороже середовище». Головною ціллю було зменшення міграції з сотень до десятків тисяч (орієнтовно до рівня 1997 р.). Одним із перших заходів, запроваджених T. Мей були так звані вантажівки з плакатами «go home», які їздили в багатоетнічних районах Лондона і залякували нелегалів або їхати додому, або бути заарештованими [20, с. 171].

Одним 3 найбільш очевидних безпосередніх прямих наслідків політики «ворожого середовища» був скандал «Віндраш», коли громадяни Співдружності, які легально проживали в Британії були оголошені нелегалами, втратили роботу, доступ до соціальних і медичних служб, і зрештою частина 3 них була депортована. Вина за це покладається прямо на плечі Т. Мей. 19 березня 2020 р. МВС випустило звіт, який був результатом незалежного розслідування скандалу; в звіті ішлося про невиправдану «необізнаність і необдуманість» і рекомендувалося провести повний огляд імміграційної політики «ворожого середовища».

Зазначимо, що саме Т. Мей вперше запровадила обмеження на в'їзд кваліфікованих мігрантів, передусім лікарів та IT-спеціалістів. Після квітня 2011 р. більш ворожим стало відношення і до міжнародних студентів, оскільки саме в них вбачали потенційних економічних мігрантів, тому до них ставили вищі освітні вимоги та складнішу бюрократичну процедуру для отримання візи [25, с. 32$]$.

У червні 2012 p. Т. Мей оголосила про запровадження нових обмежень щодо сімейних мігрантів, зокрема з країн не-СС. Складнішою ставала процедура возз'єднання сім'ї чи запрошення родичів. Iз 2012 р. розпочалася боротьба з тими, хто може приховувати злочинців як членів сім’і, прикриваючись правами людини і ухиляючись від депортації. Було позбавлено права апеляції відвідувачів сімей, що приїжджали до Великобританії. Т. Мей започаткувала ряд заходів щодо позбавлення громадянства, хоча реальних обертів вони набрали в 2017 р. Було запроваджено тест на доброхарактер- 
ність, для людей що хочуть отримати громадянство, що мав на меті перевірку десятирічної імміграційної історії людини [21, с. 77].

У жовтні 2013 р. Д. Кемерон у промові наголосив на необхідності зменшити кількість іммігрантів, проте наголосив на значимості висококваліфікованих працівників для Британії [21, с. 79]. Відповідно, британські ЗМІ почали висвітлювати завищену кількість мігрантів з Свропи, що викликало невдоволення британських громадян, які знайшли нову проблему - не тільки іммігранти, але й податки та вклади Британії до Євросоюзу суттєво спустошують економіку країни. Врешті-решт, Д. Кемерон пообіцяв провести референдум про доцільність Британії залишатися в Свросоюзі, що згодом вилилося у т.зв. Брексіт.

Незважаючи на це, британські ферми в 2013 р. просили розширити квоти для сільськогосподарських працівників саме з України, Росії та Туреччини, мотивуючи це їх трудолюбством та низькою оплатою праці. Ще в 2009 р. фермери повідомляли, що в регіоні Іст-Мідлендс лише 2,3 тис. британців із 12 тис. працівників-східноєвропейців. На їх думку, в британців немає трьох ключових якостей для праці на фермах: ентузіазму, впорядкованості дій та витримки працювати в важких умовах і обмеженому часі [16, с. 14].

Новим міграційним притоком для Великобританії став великий наплив мігрантів 3 Болгарії та Румунії в 2014 р. В той час, коли уряд очікував приїзду близько 15 тис. людей на рік, до 2016 р. їх вже було більше 100 тис. [2, с. 42]

У 2014 р. британський парламент прийняв новий Імміграційний закон, який робив Великобританію більш ворожою до нелегалів (хоча, як виявилося, до всіх мігрантів загалом). Він ускладнював процес відкриття банківського рахунку, отримання водійських права чи оренди житла. Іноземців, які мали за собою певні кримінальні порушення, спочатку депортували, а вже потім вони мали право подавати на апеляцію, що потребувало багато часу і грошей. Закон запровадив схему права на оренду, згідно з якою приватні орендодавці повинні були перевіряти імміграційний статус та не могли здавати житло в оренду нелегалам. Більше того, лендлорда могли оштрафувати на 3 тис. фунтів або ув'язнити на 5 років. Банки були зобов'язані подавали всю інформацію про власника рахунку до Імміграційної служби і заморожувати рахунок за вимогою попередньої. Натомість підприємців та інвесторів чекали більш поблажливі правила при отриманні резидентства та відкритті віз. Наголос консервативна партія робила в основному на фінансові можливості особи [13, с. 173].

Питання притулку залишалося відносно недоторканим, увага зосереджувалася в основному на пришвидшенні розгляду заяв та видачі рішень для скорочення терміну перебування апліканта в країні. Т. Мей всіляко відстоювала думку про те, що Британія не є країною для біженців.

Проте за період першого прем’ерства Д. Кемерона кількість мігрантів у Британії невпинно зростала. Частина з них приїхала за візами високоваліфікованих працівників, але влаштовувалися у сфери обслуговування або догляду за старшими людьми, що не відповідало намірам і баченням уряду в плані регулювання імміграції.

Сподіваючись остаточно взяти імміграцію під контроль для уникнення Брексіту, другий уряд Д. Кемерона прийняв в 2016 р. новий Закон про імміграцію, який робив ще жорсткішими заходи щодо роботодавців, які наймали нелегальних мігрантів - зароблені ними гроші вважалися прибутком від злочину. Правоохоронці наділялись правом проведення пошуку та конфіскації грошей і майна. Крім того, вони могли бути виселені лендлордом без всяких апеляцій. Банки і будівельні спілки час від часу зобов'язувались проводити перевірку імміграційного статусу своїх користувачів, повідомляти про закінчені візи. Гарантувався незалежний суд над затриманими, крім випадків депортації та національної небезпеки. Так звана урядова схема «спочатку депортації, пізніше оскарження» була розповсюджена на всіх мігрантів (раніше вона застосовувалася лише до засуджених злочинців). Будь-який мігрант, який подав заяву щодо порушення прав людини чи притулку, тепер міг бути вивезений до своєї країни для очікування оскарження рішення про відкликання [21, с. 79].

Згідно нового закону офіцери-прикордонники могли зупиняти човни, які плавали в прикордонних водах і перевіряти документи всіх людей, проводити обшук, застосовуючи силу, а також арештовувати. Висувалися нові вимоги до мігрантів, які працювали в громадській сфері, зокрема їм ставилась вимога вищого рівня знання мови, знання діловодства. Для мігрантів збільшувалися різні види оплат за певні довідки для роботи або документи пов'язані з їх статусом, зберігалася лише вартість заявки на паспорт. 
Референдум 2016 р., який показав мінімальну різницю між прихильниками СС (52\%) та бажаючими його залишити (48\%), вагомо вплинув на міграційну політику країни. Новою очільницею уряду стала Т. Мей, яка не мала особливої підтримки ні в парламенті, ані у власній партії. На початку ії прем'єрства щорічна міграція становила 248 тис. осіб на рік. За оцінками, чиста міграція в 2016 р. впала на 84 тис. порівняно з 2015 р. [11, с. 6]. Це падіння чистої міграції здебільшого призвело до того, що з Великобританії виїхало більше людей, переважно громадян $Є \mathrm{C}$.

Спочатку з'явилися нові вимоги до Служби охорони здоров'я. У січні 2017 p. Міністерство внутрішніх справ наказало лікарям, медсестрам та медичним працівникам обмінюватися даними про пацієнтів, дані охорони здоров'я тепер могли бути використані для «розшуку порушників імміграційних відносин».

Від червня 2016 р. з'явилися додаткові правила для шкіл - ім було наказано витрачати час на збір більше даних про дітей, включаючи їх національність та країну народження, для передачі їх Міністерству внутрішніх справ. У вищих навчальних закладах адміністратори змушені були проводити все більш інвазивні перевірки документів іноземних студентів, щоб знову передавати їх імміграційним чиновникам. Т. Мей здійснювала тиск на персонал у державних службах, усі з метою досягнення посиленого імміграційного контролю.

Після 2016 р. уряд Т. Мей взявся розробляти новий законопроєкт Про координацію імміграції та соціальне забезпечення (вихід з СС) [2, с. 41], головною метою якого було припинення права вільного руху громадян $Є С$ та змін в їх імміграційному статусі. Відповідно до нього, уряд запропонував дві нові схеми: «постійного (осілого) статусу проживання» та «попереднього осілого статусу», які діятимуть після закінчення перехідного періоду 31 грудня 2020 р. Люди, які прожили у Британії більше 5 років до 2020 р. зможуть отримати осілий статус, тим ж, хто приїхав після буде дано попередній осілий статус, після якого необхідно буде прожити ще 5 років для отримання осілого. Згідно законопроєкту, всі громадяни $Є \mathrm{C}$, які не подавали заявок на отримання постійного статусу проживання, вважаючи, що це автоматичне право, будуть депортовані. Право постійного проживання могли отримати також офіційний партнер, подружжя, діти до 21 р. і після, якщо перебувають на утриманні, батьки та утримувані особи.

У лютому 2017 р. уряд Т. Мей оприлюднив нову Білу книгу про майбутню імміграційну систему Британії, що базується на формуванні єдиної імміграційної системи після закінчення вільного руху. Передбачалася єдина система як для європейців, так і для інших громадян, незалежно від їх національності, адже до цього часу Британія приймала тільки висококваліфікованих працівників 3 решти світу, а з СС - працівників будь-якого рівня. Міністр внутрішніх справ С. Джавід описав ці пропозиції як «найбільшу зміну нашої імміграційної системи за одне покоління» [19]. Проте, зміни були зорієнтовані на те, що Британія залишить ЄС до кінця березня 2019 р., що так і не сталося. Проєкти угод Т. Мей були тричі відхилені британським парламентом від початку 2019 р., внаслідок чого в травні вона оголосила, що піде у відставку, коли буде сформовано новий уряд.

У липні 2019 р. прем’єр-міністром став Б. Джонсон, який за будь-яку ціну пообіцяв вивести Британію з Свросоюзу до 31 жовтня 2019 р. - останньої дати, яку було узгоджено з СС. У лютому 2020 р. було оприлюднено нову систему отримання робочих віз, що опирається на кількість балів і визначає категорію працівника: висококваліфікований, кваліфікований, низькокваліфікований, студент, сезонний працівник [14].

У березні 2020 р. в парламент було внесено новий законопроєкт про координації імміграції та соціального забезпечення, подібний до того, що був запропонований урядом Т. Мей. Уряд Бориса Джонсона є досить неординарним, проте в плані імміграції чітко дотримується ідеї про те, що право на приїзд до Великобританії, за словами міністра внутрішніх справ П. Пател мають тільки «найкращі та найяскравіші», якщо їх потребує британське суспільство та економіка [14].

Підсумовуючи міграційну політику британських урядів, не можна не погодитися з думкою відомого колумніста «The Guardian» та професора журналістики Р. Грінслейда про те, що тепер перші шпальти газет присвячені мігрантам зникли, виконавши свою роботу. На його думку, такі статті (3 тонко завуальованими расистськими натяками) підсвідомо підштовхували британців до підтримки Брексіту, а «міграційної кризи» у Великобританії, як такої, ніколи не було - це була криза видумана самими 3МІ [22]. На прикладі окремих осіб формувався образ цілої країни, звідки походили емігранти; приниження імміграції в газетах відображало ставлення громадськості до цієї теми. Вони вже зробили все найгірше, заохочуючи та використовуючи глибокі розбіжності в суспільстві, одночасно віддаляючи Британію від Європи. Тепер це справді криза. 


\section{Список використаних джерел та літератури:}

1. Андреева Т. Основные направления иммиграционной политики Великобритании и ЕС. Мировая экономика и международные отночения. 2001. № 9. С. 100-113.

2. Воєвода М., Колодяжна В. Нормативно-правове регулювання права притулку у Великобританії. Iсторико-правовий часопис. 2018. № 1. С. 38-43.

3. Зубарев А. Политика Великобритании в сфере предоставления убежища в 1990-1997 гг. Журнал международного права и международных отношений. 2009. № 3. С. 64-68.

4. Міхавчук Л. Лібералізація британської імміграційної політики на початку ХXI ст.: передумови та наслідки. Вісник Дніпропетровського університету. Серія: Філософія. Соиіологія. Політологія. 2015. № 1. C. $128-137$.

5. Міхавчук Л. Політика Великобританії у сфері надання притулку в кінці 1980-х - на початку 2000-х років. Молодий вчений. 2014. № 12(2). С. 289-293.

6. Asylum and Immigration Act 2004. URL: http://www. legislation.gov.uk/ukpga/2004/19/contents. (Last accessed: 16.09.2020).

7. Bloch A. A new era or more of the same? Asylum policy in the UK. Journal of refugee studies. 2000. Vol. 13. № 1. P. 29-42.

8. Browne A. Do we need mass immigration? Sussex: Hartington Fine Arts Ltd, 2002. 173 p.

9. Düvell F. Ukraine - Europe's Mexico? Research Resources Report 1/3: Country Profile, COMPAS, University of Oxford, 2006. 9 p.

10. Dwyer P., Lewis H., Scullion L., Waite L. Forced Labour and UK Immigration Policy: Status matters? Joseph Rowntree Foundation, 2011.67 p.

11. Fernández-Reino M. Briefing: Migrants in the UK labour market: an overview. Migration observatory, 2019. $15 \mathrm{p}$.

12. Finch T., Goodhart D. Immigration under Labour. London, Prospect Books, 2010. 48 p.

13. Harvey C. Restructuring asylum: recent trends in United Kingdom asylum law and policy. International Journal of refugee law. 1997. Vol. 8. N. 1. P. 60-73.

14. Home Secretary announces new UK points-based immigration system. URL:https://www.gov.uk/government/ news/home-secretary-announces-new-uk-points-based-immigration-system (Last accessed: 24.09.2020).

15. Immigration and Asylum Act 1999. URL: http:// www.legislation.gov.uk/ukpga/1999/33/contents (Last accessed: 21.10 .2020$)$.

16. Kubal A., Bakewell O. De Haas H. The Evolution of Ukrainian Migration to the UK. Scoping Study Report. International Migration Institute, University of Oxford, 2011.37 p.

17. Nationality, Immigration and Asylum Act 2002. URL: http://www.legislation.gov.uk/ukpga/2002/41/contents (Last accessed: 24.09.2020).

18. New immigration system: what you need to know. URL: https://www.gov.uk/guidance/new-immigrationsystem-what-you-need-to-know\#skilled-workers (Last accessed: 30.09.2020).

19. No 10: UK aim is to restore independence from EU by end of year. URL: https://www.theguardian.com/ politics/2020/feb/24/no-10-uk-aim-is-to-restore-independence-from-eu-by-end-of-year (Last accessed: 2.10.2020).

20. Partos R., Bale T. Immigration and asylum policy under Cameron's Conservatives. British Politics. 2015. № 10 (2). P. 169-184.

21. Robinson D. Migration policy under the coalition government. People, Place and Policy. 2013. № 7/2. P. 73-81.

22. The Observer view on the government's immigration plans. URL: https://www.theguardian.com/ commentisfree/2020/feb/23/observer-view-on-immigration (Last accessed: 11.10.2020).

23. UK Borders Act 2007. URL: http://www.legislation.gov.uk/ukpga/2007/30/contents (Last accessed: 11.10.2020).

24. Vollmer B., Malynovska O. Research on Ukrainian Migration - before and after the year 1991. Ukrainian Migration to the European Union - Lessons from Migration Studies. New York: Springer VS, 2016. 14 p.

25. Wadsworth J. The UK labour market and immigration. National Institute Economic Review. 2010. № 213(1). P. $35-42$.

26. Wagner J. Changing Immigration System: Immigration Policies Under Tony Blair and Gordon Brown. The Washington University International Review. 2012. Vol. 1. P. 22-39.

\section{References}

1. Andreeva T. Osnovnye napravleniya immigratsionnoy politiki Velikobritanii i ES. Mirovaya ekonomika $i$ mezhdunarodnye otnosheniya. 2001. № 9. S. 100-113.

2. Voievoda M., Kolodiazhna V. Normatyvno-pravove rehuliuvannia prava prytulku u Velykobrytanii. Istorykopravovyi chasopys. 2018. № 1. S. 38-43.

3. Zubarev A. Politika Velikobritanii v sfere predostavleniya ubezhishcha v 1990-1997 gg. Zhurnal mezhdunarodnogo prava i mezhdunarodnykh otnosheniy. 2009. № 3. S. 64-68.

4. Mikhavchuk L. Liberalizatsiia brytanskoi immihratsiinoi polityky na pochatku XXI st.: peredumovy ta naslidky. Visnyk Dnipropetrovskoho universytetu. Seriia : Filosofiia. Sotsiolohiia. Politolohiia. 2015. № 1. S. 128-137.

5. Mikhavchuk L. Polityka Velykobrytanii u sferi nadannia prytulku v kintsi 1980-kh - na pochatku 2000-kh rokiv. Molodyi vchenyi. 2014. № 12(2). S. 289-293.

6. Asylum and Immigration Act 2004. URL: http://www. legislation.gov.uk/ukpga/2004/19/contents. (Last accessed: 16.09.2020). 
7. Bloch A. A new era or more of the same? Asylum policy in the UK. Journal of refugee studies. 2000. Vol. 13. № 1. P. 29-42.

8. Browne A. Do we need mass immigration? Sussex: Hartington Fine Arts Ltd, 2002. 173 p.

9. Düvell F. Ukraine - Europe's Mexico? Research Resources Report 1/3: Country Profile, COMPAS, University of Oxford, 2006. 9 p.

10. Dwyer P., Lewis H., Scullion L., Waite L. Forced Labour and UK Immigration Policy: Status matters? Joseph Rowntree Foundation, 2011. 67 p. $15 \mathrm{p}$.

11. Fernández-Reino M. Briefing: Migrants in the UK labour market: an overview. Migration observatory, 2019.

12. Finch T., Goodhart D. Immigration under Labour. London, Prospect Books, 2010. 48 p.

13. Harvey C. Restructuring asylum: recent trends in United Kingdom asylum law and policy. International Journal of refugee law. 1997. Vol. 8. N. 1. P. 60-73.

14. Home Secretary announces new UK points-based immigration system. URL:https://www.gov.uk/government/ news/home-secretary-announces-new-uk-points-based-immigration-system (Last accessed: 24.09.2020).

15. Immigration and Asylum Act 1999. URL: http:// www.legislation.gov.uk/ukpga/1999/33/contents (Last accessed: 21.10.2020).

16. Kubal A., Bakewell O., De Haas H. The Evolution of Ukrainian Migration to the UK. Scoping Study Report. International Migration Institute, University of Oxford, 2011. 37 p.

17. Nationality, Immigration and Asylum Act 2002. URL: http://www.legislation.gov.uk/ukpga/2002/41/contents. (Last accessed: 24.09.2020).

18. New immigration system: what you need to know. URL: https://www.gov.uk/guidance/new-immigrationsystem-what-you-need-to-know\#skilled-workers (Last accessed: 30.09.2020).

19. No 10: UK aim is to restore independence from EU by end of year. URL: https:/www.theguardian.com/ politics/2020/feb/24/no-10-uk-aim-is-to-restore-independence-from-eu-by-end-of-year (Last accessed: 2.10.2020).

20. Partos R., Bale T. Immigration and asylum policy under Cameron's Conservatives. British Politics. 2015. № 10 (2). P. 169-184.

21. Robinson D. Migration policy under the coalition government. People, Place and Policy. 2013. № 7/2. P. 73-81.

22. The Observer view on the government's immigration plans. URL: https://www.theguardian.com/ commentisfree/2020/feb/23/observer-view-on-immigration (Last accessed: 11.10.2020).

23. UK Borders Act 2007. URL: http://www.legislation.gov.uk/ukpga/2007/30/contents (Last accessed: 11.10.2020).

24. Vollmer B., Malynovska O. Research on Ukrainian Migration - before and after the year 1991. Ukrainian Migration to the European Union - Lessons from Migration Studies. New York: Springer VS, 2016. 14 p.

25. Wadsworth J. The UK labour market and immigration. National Institute Economic Review. 2010. № 213(1). P. 35-42.

26. Wagner J. Changing Immigration System: Immigration Policies Under Tony Blair and Gordon Brown. The Washington University International Review. 2012. Vol. 1. P. 22-39. 